\title{
Amino acid transport and exchange in preimplantation mouse embyros
}

\author{
P. L. Kaye*†, G. A. Schultz*, M. H. Johnson $\neq$, Hester P. M. Pratt $\ddagger$ \\ and R. B. Church* \\ * Department of Medical Biochemistry, University of Calgary, Calgary, Alberta, Canada \\ $T 2 N 1 N 4$ and $\ddagger$ Department of Anatomy, Downing Street, Cambridge CB2 3DY, U.K.
}

\begin{abstract}
Summary. Between the 1-cell zygote and the early blastocyst stage of mouse embryos the net rate of uptake of methionine increased, the internal pool became progressively more expanded and less easily reached steady state, and the specificity of competitor amino acids changed. Sodium-dependent transport was first detected in compacted morulae (16-32-cell stage). Uptake of $\left[{ }^{14} \mathrm{C}\right]$ methylaminoisobutyric acid was detectable in blastocysts but not in unfertilized eggs. Efflux of methionine by an exchange transport system was detectable at all stages, but in intact blastocysts much higher external concentrations were required to activate exchange transport. An exchange system with properties similar to that operating at cleavage stages was exposed when blastocysts were collapsed with cytochalasin D. Since this exchange system was not detectable in isolated inner cell masses, it may be confined to the juxtacoelic surface of trophectoderm cells.
\end{abstract}

\section{Introduction}

The uptake of exogenously supplied amino acids by preimplantation mouse embryos has been shown to increase markedly after the 8-cell stage (Tasca \& Hillman, 1970; Brinster, 1971; Epstein \& Smith, 1973). At the 4-cell stage, the transport system for leucine and methionine has been shown to be $\mathrm{Na}^{+}$-independent (Borland \& Tasca, 1974) and appears to be almost identical kinetically to the system involved in transport of methionine in unfertilized and fertilized eggs (Holmberg \& Johnson, 1979). Both have a $K_{\mathrm{m}}$ for uptake of about $6 \times 10^{-5} \mathrm{M}$ (Borland \& Tasca, 1974; Holmberg \& Johnson, 1979) and, on the basis of specificity of uptake, share many of the properties of the L system described initially for Ehrlich cells by Oxender \& Christensen (1963). The uptake system in the unfertilized and fertilized eggs is linked to an efflux system with similar amino acid specificity (Holmberg \& Johnson, 1979). By the blastocyst stage, methionine uptake is partly $\mathrm{Na}^{+}$-dependent and exhibits complex kinetics suggestive of at least two transport systems, one with a $K_{\mathrm{m}}$ similar to that of eggs and early cleavage embryos and one with a higher $K_{\mathrm{m}}$ of $8.9 \times 10^{-4} \mathrm{M}$ (Borland \& Tasca, 1974). The present studies were undertaken to characterize further the system for transport and exchange of methionine in preimplantation mouse embryos at different developmental ages.

† Present address: Department of Physiology and Pharmacology, University of Queensland, St Lucia, Queensland, Australia 4067. 


\section{Materials and Methods}

\section{Superovulation and collection of eggs and embryos}

Random-bred HC-CFLP mice (Hacking and Churchill, Alconbury, U.K.) at 4-6 weeks of age or ALAS mice (Laboratory Animal Breeding Services, University of Alberta, Edmonton, Alberta, Canada) at 7-8 weeks of age were induced to superovulate as described previously (Holmberg \& Johnson, 1979). Unfertilized eggs were recovered 14-20 h after hCG injection and freed from cumulus cells by hyaluronidase treatment followed by several washes in phosphate-buffered medium containing $4 \mathrm{mg}$ bovine serum albumin $/ \mathrm{ml}(\mathrm{PB} 1+\mathrm{BSA})$ as described by Holmberg \& Johnson (1979). Embryos were recovered by flushing oviducts or uteri from mated animals at the times indicated. Morphologically abnormal or retarded embryos at any given stage were discarded.

\section{Assay of L-methionine uptake}

In all the experiments outlined below, L- $\left[{ }^{35} \mathrm{~S} /\right.$ methionine (sp. act. $>1000 \mathrm{Ci} / \mathrm{mmol}$ : Radiochemical Centre, Amersham, U.K.) was diluted with unlabelled L-methionine (Sigma) to yield mixtures with the appropriate specific activities indicated. For uptake measurements, eggs or embryos were placed in $1 \mathrm{ml}$ Medium PB $1+$ BSA containing $100 \mu \mathrm{M} \mathrm{L}-\mathrm{l}^{35} \mathrm{~S} \mid$ methionine (sp. act. $\sim 1 \mathrm{Ci} / \mathrm{mmol}$ ) at $37^{\circ} \mathrm{C}$. Following incubation for various times, three groups of 10 or more eggs or embryos were sampled from the culture at any given time point and then transferred through four washes each of $1 \mathrm{ml}$ Medium PB $1+$ BSA. This procedure, which involves periodic sampling and therefore cooling of the culture, yields slightly lower hourly uptake rates than occurs for cultures left at $37^{\circ} \mathrm{C}$ for $60 \mathrm{~min}$ throughout. Samples of the wash medium were assayed to check for complete removal of radioactive methionine. Washed eggs or embryos were counted directly after addition of a solubilizing cocktail (Aquasol, New England Nuclear, Boston, Massachusetts, U.S.A.). Dilutions of the labelling medium were also counted to allow an exact calculation of specific activity. Net uptake of exogenous methionine in $\mathrm{fmol} / \mathrm{embryo} / \mathrm{h}$ was calculated as described by Holmberg \& Johnson (1979).

To assess specificity of uptake, blastocysts were incubated in Medium PB1 + BSA containing $10 \mu \mathrm{M}-\mathrm{L}-\left[{ }^{35} \mathrm{~S} /\right.$ methionine (sp. act. $\sim 10 \mathrm{Ci} / \mathrm{mmol}$ ) or $10 \mu \mathrm{M}-\mathrm{L}-\left[{ }^{35} \mathrm{~S} \mid\right.$ methionine and 50 $\mu \mathrm{M}$-unlabelled competitor amino acid (leucine, phenylalanine, alanine, glycine) at $37^{\circ} \mathrm{C}$ for $1 \mathrm{~h}$. Groups of embryos were then transferred through four $1 \mathrm{ml}$ washes each of Medium PB $1+$ BSA and counted as above. In one series of experiments, $\mathbf{L}-\left[{ }^{35} S\right]$ methionine and competitor amino acids were present at $100 \mu \mathrm{M}$ and $500 \mu \mathrm{M}$ concentrations, respectively.

\section{$\mathrm{Na}^{+}$-dependence of methionine uptake}

Groups of 5-10 embryos were incubated in $25 \mu \mathrm{l}$ control Medium 16 (Whittingham, 1971) containing $140 \mathrm{mM}-\mathrm{Na}^{+}, 4 \mathrm{mg} \mathrm{BSA} / \mathrm{ml}$ and $100 \mu \mathrm{M}-\mathrm{L}-\left[{ }^{35} \mathrm{~S}\right]$ methionine $(5 \mathrm{Ci} / \mathrm{mmol})$ for $1 \mathrm{~h}$ at $37^{\circ} \mathrm{C}$ in $5 \% \mathrm{CO}_{2}$ in air under oil. Medium $16+\mathrm{BSA}$ was depleted of $\mathrm{Na}^{+}$to $20 \mathrm{~mm}$ by equimolar substitution of choline chloride for sodium chloride and potassium bicarbonate for sodium bicarbonate (Borland \& Tasca, 1974). Embryos to be incubated in $\mathrm{Na}^{+}$-depleted medium were washed thoroughly in this medium before labelling to ensure minimal carry-over of $\mathrm{Na}^{+}$. After $1 \mathrm{~h}$ embryos were washed through 10 drops of $0.1 \mathrm{ml}$ Medium $16+\mathrm{BSA}$ and counted in duplicate groups in a scintillation counter. Samples of the final wash solution and incubation medium were also counted. The uptake in terms of fmol methionine/embryo/h was calculated as described by Holmberg \& Johnson (1979) and is expressed as the mean value of duplicate experiments. Less than $5 \%$ of methionine taken up into embryos was incorporated into protein as assessed by trichloroacetic acid (TCA)-insoluble radioactivity. 


\section{Uptake of $N$-methylaminoisobutyric acid $(M e A I B)$}

Unfertilized eggs ( $16 \mathrm{~h}$ after hCG) or early blastocysts $(90 \mathrm{~h}$ after $\mathrm{hCG}$ ) were incubated at $37^{\circ} \mathrm{C}$ in $100 \mu \mathrm{l}$ Medium PB1 + BSA containing $1.93 \mathrm{~mm}-\alpha-\left[1-{ }^{14} \mathrm{C}\right] \mathrm{MeAIB}$ (sp. act. $51 \cdot 8$ $\mathrm{mCi} / \mathrm{mmol}$ : New England Nuclear) under oil for up to $2 \mathrm{~h}$. At any given time point, 3 groups of 10 eggs or blastocysts were removed from the incubation medium, transferred through four washes each of $1 \mathrm{ml}$ Medium PB 1 + BSA and counted for radioactivity as described above.

\section{Measurement of $\mathrm{L}-\left[{ }^{35} \mathrm{~S}\right]$ methionine efflux from eggs and embryos}

For exchange or efflux measurements, eggs or embryos were incubated in Medium PB1 + BSA containing $100 \mu \mathrm{M}-\mathrm{L}-\left[{ }^{35} \mathrm{~S}\right]$ methionine $(1 \mathrm{Ci} / \mathrm{mmol})$ for $1 \mathrm{~h}$ at $37^{\circ} \mathrm{C}$, washed in $1 \mathrm{ml} \mathrm{Medium}$ $\mathrm{PB} 1+\mathrm{BSA}$ and then allowed to exchange at $37^{\circ} \mathrm{C}$ after transfer to $1 \mathrm{ml}$ Medium PB1 + BSA containing unlabelled amino acid or $1 \mathrm{ml}$ Medium PB1 + BSA lacking exogenously supplied amino acid. In most cases, the exchange wash medium contained $100 \mu \mathrm{M}$ unlabelled L-methionine although in some experiments various concentrations of methionine or other amino acids were used. After various incubation times, 3 groups of 10 or more eggs or embryos were sampled, washed, and counted as described above.

Some of the results are expressed as percentage specific efflux by exchange, i.e. ((Rc $-\mathrm{Rm})$ / Ro) $\times 100$, where $\mathrm{Ro}=$ fmol exogenous methionine taken up per embryo after $1 \mathrm{~h}$ incubation in labelling medium; $\mathrm{Rc}=$ fmol exogenous methionine remaining per embryo after $40 \mathrm{~min}$ in wash medium free of exogenous amino acid; and $\mathrm{Rm}=$ fmol exogenous methionine remaining after 40 min in wash medium containing unlabelled methionine or other amino acid.

\section{Exchange of amino acids accompanying methionine intracellular pool expansion}

Groups of 1000 or more unfertilized eggs and 500 or more blastocysts were incubated in Medium PB $1+$ BSA containing L- $\left[{ }^{35} S\right.$ methionine at a concentration of $100 \mu \mathrm{M}(1 \mathrm{Ci} / \mathrm{mmol})$ at $37^{\circ} \mathrm{C}$ for 1 (eggs) or 2 (blastocysts) h. They were then washed four times in Medium PB $1+$ BSA, TCA-soluble extracts were prepared, and amino acids were resolved and measured on a Beckman $121 \mathrm{M}$ Amino Acid Analyzer modified for fluorescence detection with $o$ phthalaldehyde as described by Schultz, Kaye, McKay \& Johnson (1981). Samples (5 $\mu$ l) of the incubation medium were analysed. Each amino acid peak eluting from the analyser was collected and radioactivity was determined in an Aquasol cocktail at $67 \%$ counting efficiency. Between 85 and $90 \%$ of the radioactivity eluted with the methionine peak in the medium and intracellular pool preparations. The remainder resolved as oxidized methionine and co-eluted with aspartic acid. The specific activity of methionine in both the medium and intracellular pool was calculated. The medium contained little contamination by amino acids other than exogenously supplied methionine and norleucine, which was added as an internal standard at the time of TCA extraction to monitor losses through manipulative procedures (Text-figs $2 \mathrm{c}$ and $2 \mathrm{f}$ ).

\section{Methionine uptake and exchange in cytochalasin $D$-treated embryos}

Embryos were recovered at $52 \mathrm{~h}$ (4-cell) or $98 \mathrm{~h}$ (early blastocyst) after hCG from HC-CFLP mice. Embryos recovered at $52 \mathrm{~h}$ after hCG were cultured in Medium $16+$ BSA containing $0.5 \mu \mathrm{g}$ cytochalasin $\mathrm{D} / \mathrm{ml}$ which blocks division but allows maturation of other developmental features to proceed on a normal time-table (Pratt, Chakraborty \& Surani, 1981). These embryos, termed 'cytochalasin D-continuous', were kept in medium containing cytochalasin $\mathrm{D}$ until $100 \mathrm{~h}$ and then were cultured in medium containing 100 $\mu \mathrm{M}-\mathrm{L}-\left[{ }^{35} \mathrm{~S}\right]$ methionine $(5 \mathrm{Ci} / \mathrm{mmol})$ plus cytochalasin $\mathrm{D}(0.5 \mu \mathrm{g} / \mathrm{ml})$ for $60 \mathrm{~min}$ before transfer to wash media. Some embryos were sampled for counting. Others were placed for $40 \mathrm{~min}$ at $37^{\circ} \mathrm{C}$ 
in medium plus cytochalasin $\mathrm{D}(0.5 \mu \mathrm{g} / \mathrm{ml})$ and either containing or lacking unlabelled methionine $(100 \mu \mathrm{M})$. Measurement of radioactivity in the embryos at the end of this period was performed by the procedures described above.

Some embryos recovered at $99 \mathrm{~h}$ after hCG were exposed to $0.5 \mu \mathrm{g}$ cytochalasin $\mathrm{D} / \mathrm{ml}$ for 1 $\mathrm{h}$ only, which caused collapse and decompaction. These embryos were then kept in cytochalasin-containing media throughout labelling, washing and exchange as described above and are termed 'cytochalasin D-collapsed'. Results were expressed as percentage specific efflux by exchange, calculated according to the equation presented earlier. Control embryos recovered at $100 \mathrm{~h}$ after hCG and treated similarly but in medium lacking cytochalasin D were included for comparison.

In a final set of manipulations, inner cell masses were isolated from blastocysts $100 \mathrm{~h}$ after hCG by immunosurgery as described by Handyside (1978). One group of inner cell masses was exposed to cytochalasin D and a second group was handled as controls just as in the 'cytochalasin D-collapsed' experiment. Again, radioactivity was measured and results expressed as percentage specific efflux by exchange.

\section{Nomenclature}

Abbreviations and single letter codes for amino acids are used as defined by the IUPAC-IUB (Biochem.J. 113, 1-4, 1969). Taurine has been abbreviated as Tau. $\alpha$-Aminoisobutyric acid has been abbreviated as AIB. $N$-methylaminoisobutyric acid has been abbreviated as MeAIB.

\section{Statistical analysis}

The significance of differences between groups was assessed by applying Student's $t$ test and values of $P<0.01$ were regarded as significant.

\section{Results}

\section{Kinetics of L-methionine uptake}

The net uptake of $\mathrm{L}-\left[{ }^{35} \mathrm{~S}\right]$ methionine in fertilized eggs approached a plateau of approximately $200 \mathrm{fmol} / \mathrm{egg}$ after $60 \mathrm{~min}$ (Text-fig. 1). A similar result was obtained for unfertilized eggs and 2-cell ( $40 \mathrm{~h}$ after $\mathrm{hCG}$ ) embryos (data not presented). In late 4-cell embryos net uptake of $\mathrm{L}-\left[{ }^{35} \mathrm{~S} \mid\right.$ methionine over $60 \mathrm{~min}$ was twice that of the unfertilized egg and had not reached an equilibrium at this time (Text-fig.1). At each later stage examined, including precompacted 8-cell embryos, compacted morulae and early blastocysts, net uptake was increased progressively and the intracellular pool was progressively less saturable (Text-fig. 1). For example, net uptake by the blastocysts continued to increase progressively for at least $2 \mathrm{~h}$ and reached levels greater than $2500 \mathrm{fmol} /$ blastocyst. Incorporation of $\mathrm{L}-\left[{ }^{35} \mathrm{~S}\right]$ methionine into TCA-insoluble material was less than $7 \%$ of the total uptake value at $60 \mathrm{~min}$ in all stages examined.

\section{Competition of amino acid uptake}

In addition to the marked increase in rate of methionine uptake, blastocysts ( $96 \mathrm{~h}$ after hCG) also exhibited altered specificity of transport compared to eggs. In eggs, leucine and phenylalanine which are highly reactive substrates for the L system of Christensen (1975), are effective competitors with $\mathrm{L}-\left[{ }^{35} \mathrm{~S} \mid\right.$ methionine for uptake whereas alanine and glycine, which are preferred substrates for the A system of Christensen (1975), are not effective as competitors (Table 1). A similar specificity was observed at the 4-cell stage by Borland \& Tasca (1974). In the blastocyst, leucine and phenylalanine remain effective competitors, but glycine and alanine also compete 


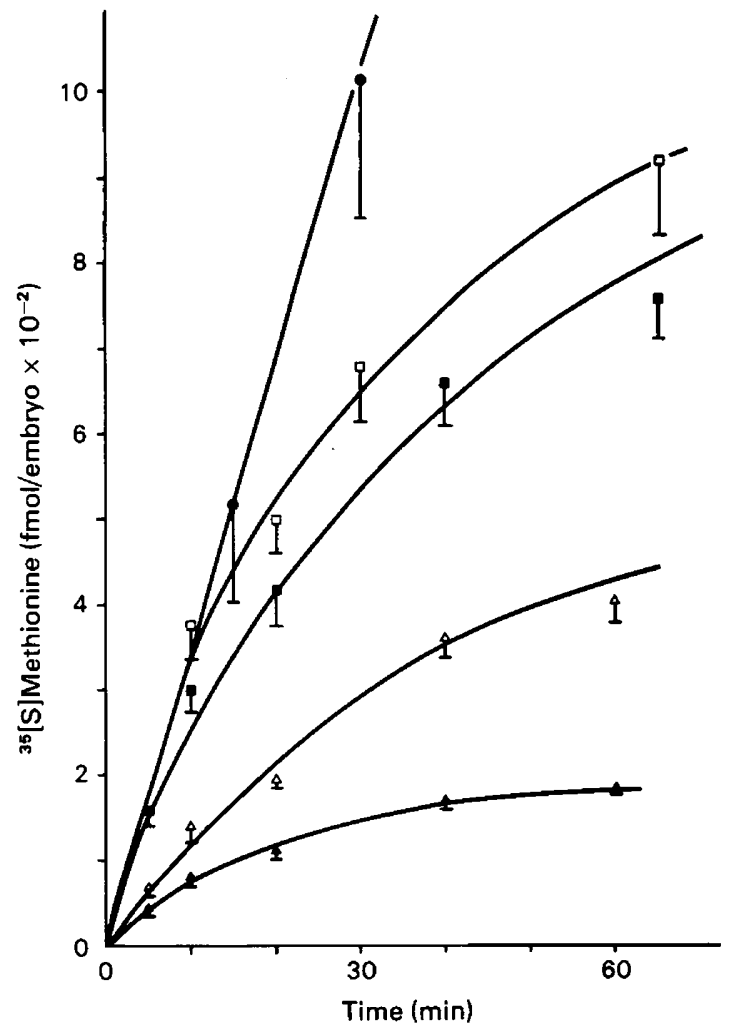

Text-fig. 1. Net uptake of $\mathrm{L}-\left[{ }^{35} \mathrm{~S}\right]$ methionine in preimplantation mouse embryos. Eggs or embryos were incubated at $37^{\circ} \mathrm{C}$ in $1 \mathrm{ml}$ Medium PB1 + BSA containing $100 \mu \mathrm{M}$ $\mathrm{L}-\left[{ }^{35} \mathrm{~S}\right]$ methionine $(1 \mathrm{Ci} / \mathrm{mmol})$. At the times indicated, 3 groups of 10 or more eggs or embryos were sampled, washed extensively, counted and the counts converted to fmol exogenous methionine. Points reflect the mean of groups at each time point and the bar indicates the standard deviation. $\Delta$, Fertilized eggs ( $16 \mathrm{~h}$ after hCG); $\triangle$, 4-cell embryos ( $60 \mathrm{~h}$ after $\mathrm{hCG}$ ); $\mathbf{E}$, uncompacted 8-cell embryos ( $72 \mathrm{~h}$ after hCG); $\square$, compacted morulae ( $83 \mathrm{~h}$ after hCG); early blastocysts ( $96 \mathrm{~h}$ after hCG).

Table 1. Effect of unlabelled amino acids in the incubation medium on net methionine uptake into eggs and blastocysts incubated in $10 \mu \mathrm{M}$ L- $\left[{ }^{35} \mathrm{~S}\right]$ methionine

\begin{tabular}{lrc}
\hline \multirow{2}{*}{\multicolumn{1}{c}{ Competitor }} & \multicolumn{2}{c}{ Net uptake (\% control) } \\
\cline { 2 - 3 } \cline { 2 - 3 } & Egg* $^{*}$ & Blastocyst \\
\hline None & 100 & 100 \\
Leucine $(50 \mu \mathrm{M})$ & 14 & 15 \\
Phenylalanine $(50 \mu \mathrm{M})$ & 23 & 28 \\
Glycine $(50 \mu \mathrm{M})$ & 117 & 44 \\
Alanine $(50 \mu \mathrm{M})$ & 94 & 49 \\
AIB $(50 \mu \mathrm{M})$ & 106 & 98 \\
\hline
\end{tabular}

* Data from Holmberg \& Johnson (1979) except for AIB value; eggs obtained $16 \mathrm{~h}$ after hCG, incubation for $60 \mathrm{~min}$.

+ Embryos obtained $96 \mathrm{~h}$ after hCG, incubated for $60 \mathrm{~min}$. 
with $\mathrm{L}-\left[{ }^{35} \mathrm{~S}\right]$ methionine for uptake at this stage (Table 1). Similar results were obtained when the experiment of Table 1 was conducted with $100 \mu \mathrm{M} \mathrm{L}-\left[{ }^{35} \mathrm{~S}\right]$ methionine and $500 \mu \mathrm{M}$ concentrations of competitor amino acids (data not presented). Aminoisobutyric acid was not an effective competitor for methionine in the preimplantation embryo (Table 1).

\section{Effect of $\mathrm{Na}^{+}$on uptake of methionine}

The development of $\mathrm{Na}^{+}$-dependence was investigated by comparing the net uptake of methionine $(100 \mu \mathrm{M})$ by embryos of different ages in the presence or absence of $\mathrm{Na}^{+}$ions (Table 2). $\mathrm{Na}^{+}$-dependent uptake was first detected in embryos recovered $80 \mathrm{~h}$ after hCG. This dependence developed whether or not embryos were grown in the presence of cytochalasin D which prevents expansion of morulae to blastocysts and which collapses expanded blastocysts (Table 2).

Table 2. Effect of $\mathrm{Na}^{+}$on the net uptake of methionine into eggs and preimplantation mouse embryos

\begin{tabular}{|c|c|c|c|c|}
\hline \multirow{2}{*}{$\begin{array}{c}\text { Age of } \\
\text { embryo } \\
\text { (h after hCG) }\end{array}$} & \multirow{2}{*}{$\begin{array}{l}\text { Stage } \\
\text { of } \\
\text { embryo }\end{array}$} & \multirow[b]{2}{*}{ Treatment } & \multicolumn{2}{|c|}{$\begin{array}{c}\text { Uptake } \\
\text { (fmol/embryo/h) }\end{array}$} \\
\hline & & & $+\mathrm{Na}^{+}$ & $-\mathrm{Na}^{+}$ \\
\hline 18 & Unfertilized eggs & - & $285 \pm 24$ & $266 \pm 26$ \\
\hline 50 & 4-cell & - & $573 \pm 17$ & $536 \pm 8$ \\
\hline 80 & $\begin{array}{l}\text { Compacted morulae } \\
(16-32 \text {-cell })\end{array}$ & - & $1486 \pm 209$ & $772 \pm 42$ \\
\hline 80 & $\begin{array}{l}\text { Non-compacted } \\
\text { morulae* }\end{array}$ & $\begin{array}{l}\text { Cytochalasin D present } \\
\text { for } 30 \mathrm{~h}\end{array}$ & $1652 \pm 210$ & $990 \pm 46$ \\
\hline 100 & Blastocyst & - & $4003 \pm 244$ & $2018 \pm 223$ \\
\hline 100 & $\begin{array}{l}\text { Blastocyst-like } \\
\text { vesicles }{ }^{\dagger}\end{array}$ & $\begin{array}{l}\text { Cytochalasin D present } \\
\text { for } 30 \mathrm{~h}\end{array}$ & $3434 \pm 202$ & $2343 \pm 130$ \\
\hline
\end{tabular}

Values are the mean \pm s.e.m. for 4 observations.

* 4-cell embryos (50 h after hCG) were incubated in cytochalasin D $(0.5 \mu \mathrm{g} / \mathrm{ml})$ until $80 \mathrm{~h}$ after hCG when they were assayed in the presence of cytochalasin D.

† 4-cell embryos were incubated with cytochalasin $\mathrm{D}$ as in * but were removed from medium containing the drug at $80 \mathrm{~h}$ after hCG and cultured for a further $20 \mathrm{~h}$ in medium lacking cytochalasin D. These embryos accumulated fluid to form (4-cell) 'blastocyst-like vesicles' (Pratt et al., 1981) and were assayed for uptake at $100 \mathrm{~h}$ after hCG.

\section{Uptake of $\left[{ }^{14} \mathrm{C}\right] \mathrm{MeAIB}$}

$N$-Methylaminoisobutyric acid is a non-metabolizable amino acid analogue which appears to be transported exclusively by the $\mathrm{Na}^{+}$-dependent A system in mammalian cells (Christensen, 1979). Unfertilized eggs incubated in $1.93 \mathrm{~mm}-\left[{ }^{14} \mathrm{C}\right] \mathrm{MeAIB}$ for up to $80 \mathrm{~min}$ took up very little of this substrate (Table 3 ), the value being barely detectable above radioactivity remaining in the

Table 3. Uptake of $\left[{ }^{14} \mathrm{C}\right] \mathrm{MeAIB}$ by mouse eggs and blastocysts

\begin{tabular}{ccc}
\hline Stage & $\begin{array}{c}\text { Incubation } \\
\text { time }(\mathrm{min})\end{array}$ & $\begin{array}{c}\text { Net uptake of }\left[{ }^{14} \mathrm{C}\right] \mathrm{MeAIB} \\
\text { (d.p.m./egg or embryo) }\end{array}$ \\
\hline Unfertilized egg & 20 & $5 \pm 1$ \\
(16 h after hCG) & 80 & $8 \pm 2$ \\
Blastocyst & 30 & $38 \pm 12$ \\
(90 h after hCG) & 120 & $81 \pm 10$ \\
\hline
\end{tabular}

* Each value is the mean \pm s.e.m. derived from counting 3 groups of 10 eggs or blastocysts. Counting efficiency was $71 \%$. 
wash media. Because the isotope is of low specific activity, it is difficult to assess whether the low values have any significance. In $90 \mathrm{~h}$ blastocysts incubated under the same conditions, the amount of $\left[{ }^{14} \mathrm{C}\right] \mathrm{MeAIB}$ taken up was markedly increased, being readily detectable at $30 \mathrm{~min}$ and still greater at $120 \mathrm{~min}$ (Table 3) when the equivalent to $710 \mathrm{fmol}\left[{ }^{14} \mathrm{C}\right] \mathrm{MeAIB} / \mathrm{blastocyst}$ was taken up.

\section{Exchange of $\mathrm{L}-\left[{ }^{35} S\right]$ methionine in preimplantation mouse embryos}

At all stages up to the compacted morula, a marked efflux of $\mathrm{L}-\left[{ }^{35} \mathrm{~S}\right]$ methionine was observed when external methionine was provided for exchange (Text-fig. 2). In blastocysts, however, the relative amount of $\mathbf{L}-\left[{ }^{35} \mathrm{~S}\right]$ methionine loss from preloaded embryos transferred to medium containing $100 \mu \mathrm{M}$-methionine was markedly less than that observed for earlier stage embryos and was not measurably different from $\mathrm{L}^{\mathrm{j}}\left[{ }^{35} \mathrm{~S}\right]$ methionine loss to medium lacking amino acid (Text-fig. 2). Exchange was occurring in these blastocysts (see below) but the amount of exchange relative to uptake was small.

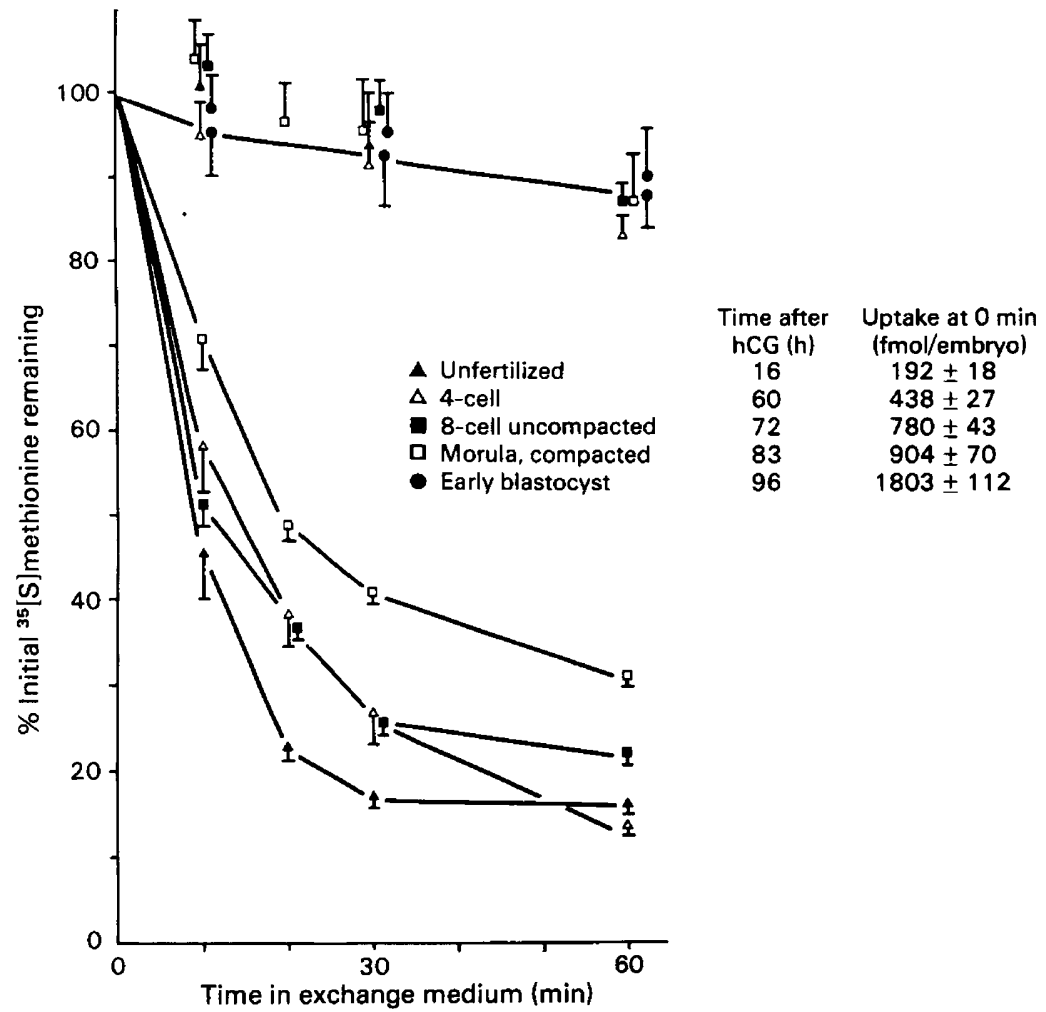

Text-fig. 2. Exchange of $\left.\mathrm{L}^{-}{ }^{33} \mathrm{~S}\right]$ methionine in preimplantation mouse embryos with unlabelled methionine in the culture medium. Eggs or embryos were incubated at $37^{\circ} \mathrm{C}$ in $1 \mathrm{ml}$ Medium PB1 + BSA containing $100 \mu \mathrm{M} \mathrm{L}-\left[{ }^{35} \mathrm{~S}\right]$ methionine $(1 \mathrm{Ci} / \mathrm{mmol})$ for $60 \mathrm{~min}$. At the end of this uptake period, eggs or embryos were washed once in $1 \mathrm{ml}$ Medium PB $1+$ BSA and transferred to new incubation dishes containing Medium PB1 + BSA or Medium PB $1+$ BSA $+100 \mu \mathrm{M}$ unlabelled $\mathrm{L}$-methionine and incubation continued at $37^{\circ} \mathrm{C}$. At the times indicated, 3 groups of 10 or more embryos were sampled, washed extensively, and counted. The radioactivity remaining was plotted as a percentage of the $60 \mathrm{~min}$ uptake value. Symbols with standard deviation bars pointing downward and joined by solid lines reflect loss of radioactive methionine in Medium PB1 + BSA + unlabelled methionine. Symbols with standard deviation bars pointing upward reflect loss of radioactive methionine in Medium PB1 + BSA lacking exogenous amino acid. 
The effect of concentration of amino acid in the external exchange medium on $\mathrm{L}-\left[{ }^{35} \mathrm{~S}\right]$ methionine loss from preloaded eggs and blastocysts was measured (Table 4). Loss of $\mathrm{L}-{ }^{35} \mathrm{~S} \mid$ methionine due to exchange in eggs was readily detectable at medium concentrations as low as $10 \mu \mathrm{M}$ and was very marked at all higher concentrations. Loss of $\mathrm{t}\left[{ }^{35} \mathrm{~S}\right]$ methionine in blastocysts due to specific exchange was not easily measured in these types of experiments until concentrations of $1 \mathrm{~mm}$-methionine were provided in the medium. At $10 \mathrm{~mm}$-methionine concentration, efflux due to exchange was marked. The presence of neither $1 \mathrm{~mm}$-taurine (which is not transported by mouse blastocysts) nor $1 \mathrm{mM}$-AIB led to specific exchange, suggesting that exchange in $1 \mathrm{~mm}$-methionine was not simply an osmotic effect.

Table 4. Effect of concentration of amino acid in exchange medium on loss of $\left.\mathrm{L}-{ }^{35} \mathrm{~S}\right]$ methionine from mouse eggs and blastocysts

\begin{tabular}{lrcc}
\hline & & \multicolumn{2}{c}{$\begin{array}{c}\text { Percentage specific efflux after } \\
40 \mathrm{~min} \text { in exchange medium* }\end{array}$} \\
\cline { 3 - 4 } Amino acid & $\begin{array}{c}\text { External } \\
\text { conc. }\end{array}$ & $\begin{array}{c}\text { Eggs } \\
(16 \mathrm{~h} \text { after hCG })\end{array}$ & $\begin{array}{c}\text { Blastocysts } \\
(90 \mathrm{~h} \text { after hCG })\end{array}$ \\
\hline Methionine & $10 \mu \mathrm{M}$ & $57 \cdot 3$ & $3 \cdot 4$ \\
Methionine & $100 \mu \mathrm{M}$ & $79 \cdot 5$ & $5 \cdot 6,7 \cdot 2,11 \cdot 1$ \\
Methionine & $1 \mathrm{mM}$ & $85 \cdot 7$ & $36 \cdot 0,32 \cdot 2,31 \cdot 3$ \\
Methionine & $10 \mathrm{mM}$ & $87 \cdot 1$ & $65 \cdot 1$ \\
Taurine & $1 \mathrm{mM}$ & - & $5 \cdot 2,7 \cdot 2$ \\
AIB & $100 \mu \mathrm{M}$ & $2 \cdot 8$ & $3 \cdot 2$ \\
AIB & $1 \mathrm{mM}$ & - & - \\
\hline
\end{tabular}

* Eggs and blastocysts were preincubated for $60 \mathrm{~min}$ in Medium PB1 + BSA containing $100 \mu \mathrm{M} \mathrm{L}-\left[{ }^{35} \mathrm{~S}\right]$ methionine (sp. act. $1 \mathrm{Ci} / \mathrm{mmol}$ ). After one wash in Medium PB1 + BSA some embryos were sampled to determine the amount of radioactive methionine taken up and the remainder were transferred to exchange medium containing amino acid at the concentration indicated above. Controls were transferred to Medium PB1 + BSA lacking amino acid. After $40 \mathrm{~min}$, eggs and blastocysts were washed and counted to determine the amount of $\mathrm{L}-{ }^{35} \mathrm{~S} \mid$ methionine remaining. Uptake values were approximately $200 \mathrm{fmol} / \mathrm{egg}$ and $2000 \mathrm{fmol} /$ blastocyst. Percentage specific efflux was calculated as described in 'Materials and Methods'. Each value is the average calculated from 3 groups of 10 or more eggs or embryos.

In unfertilized and fertilized eggs, efflux of $\mathrm{L}-\left[{ }^{35} \mathrm{~S}\right]$ methionine in the presence of medium containing exogenous methionine $(100 \mu \mathrm{M})$ ceased after $60 \mathrm{~min}$ at residual internal levels of $12-14 \%$ of the initial uptake value and equal to about $25 \mathrm{fmol} / \mathrm{embryo}$ (Text-fig. 2). Of this residual amount, 11-12 fmol/embryo was represented by incorporation of $L-\left[{ }^{35} S\right]$ methionine into TCA-insoluble material. The remaining $13 \mathrm{fmol} / \mathrm{embryo}$ still existed as acid-soluble intracellular methionine as measured on the amino acid analyser and appears to represent a small pool of methionine which is non-exchangeable under the experimental conditions utilized (see also Holmberg \& Johnson, 1979).

\section{Specificity of exchange}

The specificity of exchange of amino acids in unfertilized eggs ( $16 \mathrm{~h}$ after hCG) and early blastocysts ( $90 \mathrm{~h}$ after hCG), in which intracellular pools were expanded by incubation in medium containing $100 \mu \mathrm{M}$-methionine, was assessed by measurement of the size of intracellular amino acid pools on an amino acid analyser (Text-fig. 3). The values obtained were compared with those obtained for the endogenous pool sizes of control eggs and blastocysts not subjected to methionine pool expansion (Table 5). 
In eggs (Text-figs $3 a$ and $3 b$; Table 5), the most notable effect of methionine pool expansion was the depletion of the exchangeable amino acids isoleucine (I), leucine (L), and phenylalanine (F) (Holmberg \& Johnson, 1979). Tyrosine (Y) and arginine (R) which were barely detectable in control eggs were reduced to non-detectable levels in methionine-treated embryos. Because of the low levels of these amino acids in control eggs, these latter observations are not likely to be significant statistically. Within the limits of standard deviations, no differences were observed in the size in eggs of any of the other amino acid pools resolved by this procedure.

Table 5. Amino acid pools in mouse eggs and blastocysts after methionine pool expansion

\begin{tabular}{|c|c|c|c|c|}
\hline \multirow[b]{3}{*}{ Amino acid } & \multicolumn{4}{|c|}{ Pool size (fmol/egg or blastocyst) } \\
\hline & \multicolumn{2}{|c|}{ Eggs ( $16 \mathrm{~h}$ after $\mathrm{hCG}$ ) } & \multicolumn{2}{|c|}{ Blastocysts ( $90 \mathrm{~h}$ after hCG) } \\
\hline & $\begin{array}{c}\text { Control } \\
(n=4-9)\end{array}$ & $\begin{array}{c}100 \mu \mathrm{M}-\mathrm{Met}^{*} \\
(n=5)\end{array}$ & $\begin{array}{c}\text { Control } \\
(n=3-5)\end{array}$ & $\begin{array}{c}100 \mu \mathrm{M}-\mathrm{Met} \dagger \\
(n=3)\end{array}$ \\
\hline Tau & $6565 \pm 335$ & $7000 \pm 411$ & $3014 \pm 537$ & $2635 \pm 80$ \\
\hline Asp (D) & $462 \pm 85$ & $407 \pm 53$ & $749 \pm 119$ & $630 \pm 51$ \\
\hline $\mathrm{Thr}+\mathrm{G} \ln \neq(\mathrm{T} \& \mathrm{Q})$ & $218 \pm 30$ & $203 \pm 40$ & $503 \pm 108$ & $200 \pm 25$ \\
\hline Ser (S) & $176 \pm 24$ & $174 \pm 28$ & $331 \pm 70$ & $220 \pm 30$ \\
\hline Glu (E) & $890 \pm 122$ & $877 \pm 101$ & $1250 \pm 183$ & $970 \pm 26$ \\
\hline Gly (G) & $3954 \pm 430$ & $4321 \pm 521$ & $335 \pm 57$ & $198 \pm 19$ \\
\hline Ala (A) & $592 \pm 66$ & $731 \pm 71$ & $349 \pm 58$ & $421 \pm 11$ \\
\hline Val (V) & $73 \pm 7$ & $80 \pm 5$ & $146 \pm 7$ & $60 \pm 6^{a}$ \\
\hline Met $(\mathrm{M})$ & $18 \pm 1$ & $248 \pm 30^{\mathrm{a}}$ & $94 \pm 30$ & $2635 \pm 122^{\mathrm{a}}$ \\
\hline lleu (I) & $22 \pm 2$ & n.d. ${ }^{a}$ & $79 \pm 11$ & $<10^{\mathrm{a}}$ \\
\hline Leu (L) & $52 \pm 5$ & n.d. ${ }^{a}$ & $115 \pm 13$ & $53 \pm 8^{b}$ \\
\hline Tyr (Y) & $<10$ & n.d. & $119 \pm 28$ & n.d. ${ }^{a}$ \\
\hline Phe (F) & $25 \pm 2$ & n.d. ${ }^{a}$ & $104 \pm 12$ & n.d. ${ }^{a}$ \\
\hline His $(\mathrm{H})$ & $19 \pm 2$ & $16 \pm 2$ & $205 \pm 76$ & $66 \pm 4$ \\
\hline Lys (K) & $85 \pm 6$ & $139 \pm 30$ & $181 \pm 10$ & $<\overline{10}^{\mathrm{a}}$ \\
\hline $\operatorname{Arg}(\mathrm{R})$ & $<\overline{10}$ & n.d. & $116 \pm 14$ & $<10^{\mathrm{a}}$ \\
\hline
\end{tabular}

Values are means \pm s.e.m. n.d., not detectable.

* Incubated in Medium PB 1 + BSA containing $100 \mu \mathrm{M}$-methionine for $1 \mathrm{~h}$. Control results are from Schultz et al. (1981).

+ Incubated in Medium PB1 + BSA containing $100 \mu \mathrm{M}$-methionine for $2 \mathrm{~h}$. Control results are from Schultz et al. (1981).

$\ddagger$ Value for Thr includes Gln which co-elutes with Thr under conditions used.

Values with letter superscripts are significantly different from the corresponding control group; a $P<0.001,{ }^{\text {b } P<0.01 \text {. }}$

In blastocysts, incubation in medium containing $100 \mu \mathrm{M}$-methionine for $2 \mathrm{~h}$ led, as expected, to a marked expansion of the methionine pool (Table 5). Concomitant with this expansion, a number of other amino acids were affected (Text-figs $3 \mathrm{~d}$ and $3 \mathrm{f}$; Table 5). As in eggs, isoleucine (I) and leucine (L) were significantly $(P<0.01)$ reduced but were still detectable. Phenylalanine (F), however, was reduced to non-detectable levels. In addition, there was a significant $(P<$ $0.001)$ reduction in valine $(\mathrm{V})$, tyrosine $(\mathrm{Y})$, lysine $(\mathrm{K})$ and arginine $(\mathrm{R})$. Threonine $(\mathrm{T})$ and glutamine $(\mathrm{Q})$ (which co-elute), glycine $(\mathrm{G})$ and histidine $(\mathrm{H})$ were all at lower levels in blastocysts in which methionine pools were expanded but these differences were not significant at $P<0.01$. In total, exchange of a number of amino acids was evident and this pattern was more complex in the blastocyst than in the egg.

At the same time that amino acids were measured after pool expansion in $\mathrm{L}^{-}\left[{ }^{35} \mathrm{~S}\right]$ methionine, amino acids eluted from the analyser were collected and counted to allow calculation of methionine-specific activity in intracellular pools compared to that of the medium. There was almost a complete equilibration of the expanded pool in both the egg and blastocyst. In the egg, the specific activity of the expanded intracellular pool was $97.8 \pm 1.1 \%$ (mean \pm s.e.m., 5 

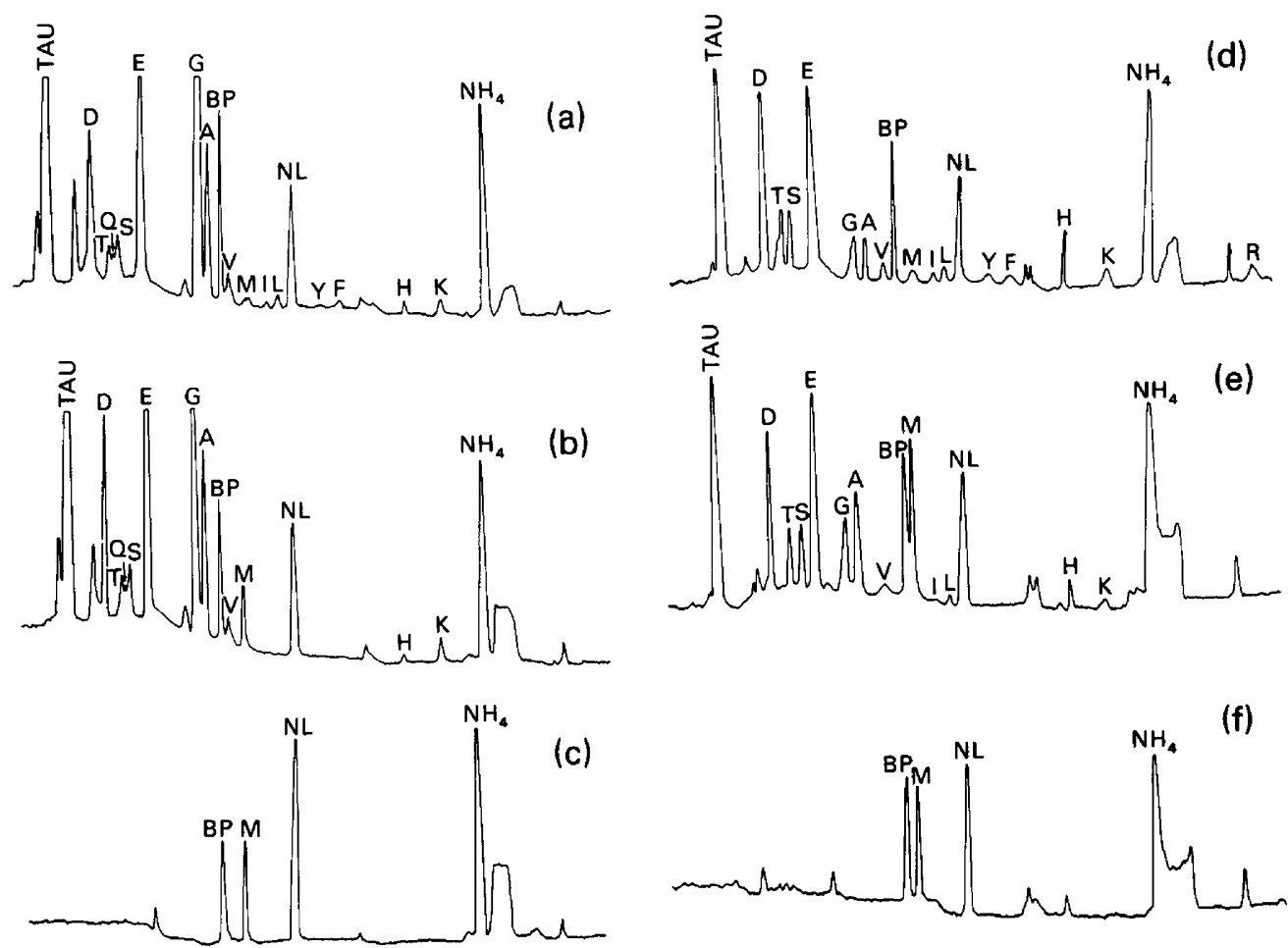

Text-fig. 3. Analysis of TCA-soluble amino acids in unfertilized mouse eggs and blastocysts before and after expansion of the methionine pool. (a) Control eggs $(N=1500)$; (b) 1600 eggs incubated in Medium PB 1 + BSA containing $100 \mu \mathrm{M}-\mathrm{L}-$ methionine for $60 \mathrm{~min}$; (c) TCA extract of $5 \mu \mathrm{l}$ Medium PB1 + BSA containing $100 \mu \mathrm{M}$-methionine used in (b); (d) 510 control blastocysts ( $90 \mathrm{~h}$ after hCG); (e) 644 blastocysts ( $90 \mathrm{~h}$ after hCG) incubated in Medium PB $1+$ BSA containing $100 \mu \mathrm{M}-\mathrm{L}$-methionine for $120 \mathrm{~min}$; (f) TCA extract of $5 \mu \mathrm{l}$ medium used in (e). Asp $=\mathrm{D}$, Thr $=\mathrm{T}$, Ser $=\mathrm{S}, \mathrm{Gln}=\mathrm{Q}, \mathrm{Glu}=\mathrm{E}, \mathrm{Gly}=\mathrm{G}, \mathrm{Ala}=\mathrm{A}, \mathrm{Val}=\mathrm{V}$, Met $=\mathrm{M}$, Ileu $=\mathrm{I}, \mathrm{Leu}=\mathrm{L}$, Norleu $=\mathrm{NL}$, Tyr $=\mathrm{Y}, \mathrm{Phe}=\mathrm{F}$, His $=\mathrm{H}$, Lys $=\mathrm{K}, \mathrm{Arg}=\mathrm{R}$. Taurine has been abbreviated as Tau and the break due to change in elution buffers as BP.

Table 6. Effect of cytochalasin D (CCD) on the exchange component of amino acid transport of mouse blastocysts

\begin{tabular}{|c|c|c|c|c|c|c|c|}
\hline \multirow{3}{*}{$\begin{array}{l}\text { Experimental } \\
\text { manipulation }\end{array}$} & \multicolumn{5}{|c|}{ Time (h) after hCG } & \multirow{3}{*}{$\begin{array}{c}\text { Net uptake* } \\
\text { (fmol/embryo/h) }\end{array}$} & \multirow{3}{*}{$\begin{array}{l}\text { Percentage } \\
\text { specific } \\
\text { efflux after } \\
40 \text { min in } \\
\text { exchange } \\
\text { medium }\end{array}$} \\
\hline & \multicolumn{2}{|c|}{$\mathrm{CCD}$} & \multicolumn{2}{|c|}{$\begin{array}{l}\mathrm{L}-\left[{ }^{35} \mathrm{~S}\right] \text { methionine } \\
(100 \mu \mathrm{M})\end{array}$} & \multirow{2}{*}{$\begin{array}{c}\text { Out of } \\
\text { exchange } \\
\text { medium }\end{array}$} & & \\
\hline & Into & Out of & Into & Out of & & & \\
\hline $\begin{array}{l}\text { Whole embryo } \\
\text { (CCD-continuous) }\end{array}$ & 52 & 102 & 100 & 101 & 102 & $1833 \pm 248$ & $62,49,98$ \\
\hline $\begin{array}{l}\text { Whole embryo } \\
\text { (CCD-collapsed) }\end{array}$ & 99 & 102 & 100 & 101 & 102 & $2023 \pm 188$ & $58,55,55$ \\
\hline Whole embryo (control) & - & - & 100 & 101 & 102 & $1999 \pm 294$ & $0,12,16,0$ \\
\hline Inner cell mass + CCD & 100 & 102 & 100 & 101 & 102 & - & 0 \\
\hline Inner cell mass (control) & - & - & 100 & 101 & 102 & - & $0,13,17,4$ \\
\hline
\end{tabular}

*Values are mean \pm s.e.m. for $40-60$ blastocysts grouped in replicates of 5 or 6 . 
observations) of that of methionine in the external medium while that in the blastocyst was $98 \cdot 3$ $\pm 1.0 \%$ (mean \pm s.e.m., 3 observations) of that of the medium.

\section{Exchange in cytochalasin D-treated blastocysts}

The results of experiments conducted under conditions in which radioactive methionine was present at a concentration of $100 \mu \mathrm{M}$ in the uptake medium and unlabelled methionine in the exchange medium was also at $100 \mu \mathrm{M}$ are summarized in Table 6 . Whereas the percentage of net accumulated methionine which is lost specifically by exchange from expanded blastocysts was rarely more than $15 \%$, the loss from cytochalasin $D$-treated embryos was over $50 \%$. The cytochalasin had no effect on the net accumulation of methionine (Table 6). There was also no detectable exchange mechanism for inner cell masses (Table 6).

\section{Discussion}

The measurements of rates of uptake of $\mathrm{L}-\left[{ }^{35} \mathrm{~S}\right]$ methionine presented here confirm and extend those reported earlier (Epstein \& Smith, 1973; Borland \& Tasca, 1974). There is a progressive increase in both rate of uptake and net uptake of methionine between the 4-cell and the blastocyst stage. By comparing transport of methionine and leucine in 4-cell embryos with that in blastocysts, Borland \& Tasca (1974) also observed an increased rate of uptake and suggested that it was due to the appearance of a second transport component with higher $K_{\mathrm{m}}$. They also showed that at some time between the 4-cell stage and the blastocyst, methionine and leucine transport became $\mathrm{Na}^{+}$-dependent. Our studies reveal that the $\mathrm{Na}^{+}$-dependence can first be observed at the compacted morula stage ( $80 \mathrm{~h}$ after hCG; 16-32-cell stage). However, since the increase in rate of uptake occurs well before the appearance of $\mathrm{Na}^{+}$-dependence (Text-fig. 1), features other than the development of $\mathrm{Na}^{+}$-dependence must underly the early changes in kinetics.

The two systems of amino acid transport postulated to explain these observations on amino acid uptake resemble, in several ways, the $\mathrm{L}$ and $\mathrm{A}$ systems defined by Christensen (1975). The $\mathrm{L}$ system of Christensen (1975) transports methionine, leucine, isoleucine and phenylalanine, is $\mathrm{Na}^{+}$-independent, and exhibits exchange kinetics. It thus has features in common with the amino acid transport system present in eggs and cleaving embryos which is also $\mathrm{Na}^{+}$-independent (Table 2), has similar specificity in competition for methionine uptake (Table 1), is highly exchangeable (Table 4) and exhibits similar specificity of exchange to that of the L system (Table 5).

The A system is a broadly reactive system having affinity for neutral amino acids with short linear or polar side chains, exhibits $\mathrm{Na}^{+}$-dependence, and is only weakly exchangeable (Christensen, 1975). In this regard, it resembles the amino acid transport system with $\mathrm{Na}^{+}$-dependence first detectable at the 16-32-cell stage in mouse embryos (Table 2). Alanine and glycine act as competitors for methionine uptake in blastocysts (Table 1) and methionine exchange properties are markedly altered in blastocysts (Text-fig. 2; Table 5) as expected of the presence of an A-like transport system. Furthermore, uptake of $\left[{ }^{14} \mathrm{C}\right] \mathrm{MeAIB}$, an analogue specific to the A system, has been demonstrated in blastocysts (Table 3). The amount of $\left[{ }^{14} \mathrm{C}\right] \mathrm{MeAIB}$ uptake we observed is similar to the $\left[{ }^{14} \mathrm{C}\right] \mathrm{AIB}$ uptake in mouse blastocysts reported by VanVinkle \& Dabich (1977) who used isotope of similar specific activity (60 $\mathrm{mCi} / \mathrm{mmol})$ at $1 \mathrm{~mm}$ concentration and obtained 52 d.p.m. $\left[{ }^{14} \mathrm{C}\right] \mathrm{AIB}$ uptake/blastocyst after 1.7 $\mathrm{h}$ and 99 d.p.m./blastocyst after $3 \mathrm{~h}$ of incubation. Uptake of $\left[{ }^{14} \mathrm{C}\right] \mathrm{AIB}$ by mouse blastocysts during experimental delay and activation has also been reported (Lindqvist, Einarsson, Nilsson \& Ronquist, 1978). However, we have not been able to demonstrate competition by AIB for methionine uptake (Table 1) or ability of AIB to stimulate efflux (Table 4) in blastocysts 
(confirming the results of Borland \& Tasca, 1974). This may be due to a higher $K_{\mathrm{m}}$ for AIB uptake or exchange in the embryos compared to that for methionine and other amino acids, as is the case in Ehrlich ascites cells (Oxender \& Christensen, 1963).

We have examined the exchange system of methionine transport in some detail. Embryos at all stages up to the blastocyst show minimum efflux of preloaded L- ${ }^{35}$ S]methionine into the medium in the absence of an external amino acid (Text-fig. 2). In the presence of methionine $(100 \mu \mathrm{M})$ in the medium, a rapid efflux of $\mathrm{L}-\left[{ }^{35} S \mid\right.$ methionine occurs from embryos up to the blastocyst stage. In blastocysts, efflux in the presence of $100 \mu \mathrm{M}$-methionine in the medium is much slower and may be dependent on internal and external methionine concentrations. We observed a greater rate of efflux with higher concentrations of methionine in the medium. The requirement of higher external methionine concentrations to cause exchange in blastocysts may be due to the higher $K_{\mathrm{m}}$ for uptake of the second transport system (Borland \& Tasca, 1974) coupled with the presence of transport molecules of an A-like system which is only weakly exchangeable (Christensen, 1975).

Eggs exchange endogenous amino acids, notably phenylalanine, tyrosine, isoleucine and leucine for external methionine (Text-fig. 3; Table 5) as expected for an L-like, $\mathrm{Na}^{+}$-independent transport system. In blastocysts, exchange is less rapid but still occurs over longer periods of time or higher external methionine concentrations. As in eggs, phenylalanine, tyrosine, leucine, and isoleucine are significantly reduced (Table 5). In addition, the internal pool sizes of a number of other amino acids are also significantly reduced during exchange, supporting the idea of the existence of more than one transport system at this stage. The fact that glycine and alanine compete for methionine uptake in blastocysts (Table 1) but are not markedly affected by exchange against external methionine (Table 5) is compatible with the presence of a weakly exchangeable, $\mathrm{Na}^{+}$-dependent, A-like system at this stage. However, such data must be interpreted cautiously when more than one transport system coexists in a cell. Operational synergy between systems can lead to intracellular accumulation of substrates when they might otherwise be exchanged (Christensen, 1975; Christensen \& Handlogten, 1968, 1979). This can be complicated at the blastocyst stage by transport of amino acids into the blastocoelic fluid such that they may either be inaccessible for exchange or result in a reduction in intracellular concentration which is incompatible with exchange (see below). A final point to consider is that while the present results suggest the presence of two transport systems, the existence of three or more systems cannot be ruled out. For example, the ASC system shares many properties of the A system in Ehrlich cells but can be distinguished from system A by its intolerance to amino acid $N$-methylation and its tendency to mediate exchange (Inui \& Christensen, 1966). The overlapping specificities of such systems can complicate the transport characteristics observed. In conclusion, some or all of the above-mentioned components might be involved in the more complex transport (uptake and exchange) properties of blastocysts compared to eggs and early cleavage-stage embryos.

The reduced rate of exchange in expanded blastocysts may also be related to morphological changes, because blastocysts collapsed with cytochalasin $\mathrm{D}$ or prevented from compacting by culture in the presence of media containing cytochalasin D exhibit exchange properties similar to those of pre-blastocyst stages. This suggests that no barrier to exchange exists in embryos which are non-cavitated but have been shown to be otherwise developmentally normal (Pratt et al., 1981). Since inner cell masses isolated immunosurgically from blastocysts do not exhibit exchange properties under the conditions utilized, the exchange system in the intact blastocyst appears to be confined largely to the basolateral surfaces of trophectoderm cells in contact with the blastocyst fluid. That is, an asymmetry might exist in trophectoderm cells of the blastocyst in which a concentrative transport system might be predominant on the outer (abcoelic) surface and an exchange system might be predominant on the inner (juxtacoelic) surface. In this context, it is relevant that $\mathrm{Na}^{+}$-dependence first appears, and rapid exchange capacity is first lost, at or shortly after the 16-32-cell stage, when a complete permeability seal of zonular tight junctions 
first develops between adjacent outer trophectoderm cells (Handyside, 1978). Upto this stage, although outer cells have a polarized or 'epithelial' morphology (Ducibella \& Anderson, 1975; Handyside, 1980; Ziomek \& Johnson, 1980; Johnson \& Ziomek, 1981), there is no evidence for heterogeneity of macromolecular distribution between apical and basolateral membranes (Johnson, 1981). This model is not unlike that proposed for epithelial cells of the gut in which amino acid transport systems are present in such a way as to maintain internal amino acid pools whilst effecting a net transport of amino acids from the gut to the blood (Christensen, 1975, 1977). The apical cell brush border is rich in transport units of an uphill (concentrative) system and the basolateral pole is rich in units of an exchange system. The former acts to concentrate amino acids into the cell and the latter to release them again. This system of molecular heterogeneity, like that we propose for trophectoderm, is maintained only for as long as the integrity of the epithelium persists (Ziomek, Schulman \& Edidin, 1980). Our cytochalasin D exchange results are compatible with such a model. Such a mechanism could allow uptake of amino acids by the blastocyst from the uterine environment with subsequent transport to the blastocyst fluid, thereby allowing accumulation of a pool of amino acids which cannot exchange with the medium. High concentrations of amino acids have been observed in blastocyst fluid (Jaszczak, Hafez, Moghissi \& Kurrie, 1972). Such a mechanism may be important in ensuring the availability of amino acid precursors for continued growth of the embryo, and in particular for the inner cell mass.

Finally, two observations on amino acid exchange in this system deserve re-emphasis because of their implications for protein synthetic studies. The first is related to the fact that methionine internal pool expansion is accompanied by the disappearance of several other amino acids. Similar observations have been made in other systems (Christensen \& Handlogten, 1979). These results suggest that care should be used in choosing conditions for experiments to measure protein synthesis such that internal pools of other amino acids are not severely depleted. Secondly, we have observed (at least in mouse eggs) that a small pool of methionine exists in the cell which is not exchangeable. This suggests the methionine pool may be compartmentalized (Holmberg \& Johnson, 1979). While the relevance of this compartmentalization to the protein synthetic apparatus is not yet known, it may have implications for studies aimed at measuring absolute rates of synthesis or turnover.

This work was supported by grants from the MRC (Canada) to G.A.S., from NSERC (Canada) to R.B.C. and from the Ford Foundation, Cancer Research Campaign and MRC (U.K.) to M.H.J. and H.P.M.P. P.L.K. is the recipient of a C.J. Martin Fellowship from the NHMRC (Australia).

\section{References}

Borland, R.M. \& Tasca, R.J. (1974) Activation of a $\mathrm{Na}^{+}$-dependent amino acid transport system in preimplantation mouse embryos. Devl Biol. 30, 169-182.

Brinster, R.L. (1971) Uptake and incorporation of amino acids by the preimplantation mouse embryo. $J$. Reprod. Fert. 27, 329-338.

Christensen, H.N. (1975) Biological Transport, 2nd edn. W. A. Benjamin Inc., Reading, Massachusetts.

Christensen, H.N. (1977) Implications of the cellular transport step for amino acid metabolism. Nutr. Rev. 35, 129-133.

Christensen, H.N. (1979) Exploiting amino acid structure to learn about membrane transport. $A d v$. Enzymol. 49, 41-101.
Christensen, H.N. \& Handlogten, M.E. (1968) Modes of mediated exodus of amino acids from Ehrlich Ascites tumour cells. J. biol. Chem. 243, 5428-5438.

Christensen, H.N. \& Handlogten, M.E. (1979) Interaction between parallel transport systems examined with tryptophan and related amino acids. J. Neural Trans. Suppl. 15, 1-13.

Ducibella, T. \& Anderson, E. (1975) Cell shape and membrane changes in the eight-cell mouse embryo: prerequisites for morphogenesis of the blastocyst. Devl Biol. 47, 45-58.

Epstein, C.J. \& Smith, S.A. (1973) Amino acid uptake and protein synthesis in preimplantation mouse embryos. Devl Biol. 33, 171-184.

Handyside, A.H. (1978) Time of commitment of inside 
cells isolated from preimplantation mouse embryos. J. Embryol. exp. Morph. 45, 37-53.

Handyside, A.H. (1980) Distribution of antibody- and lectin-binding sites on dissociated blastomeres from mouse morulae: evidence for polarization at compaction. J. Embryol. exp. Morph. 60, 99-116.

Holmberg, S.R.M. \& Johnson, M.H. (1979) Amino acid transport in the unfertilized and fertilized mouse egg. J. Reprod. Fert. 56, 223-231.

Inui, Y. \& Christensen, H.N. (1966) Discrimination of single transport systems: the $\mathrm{Na}^{+}$sensitive transport of neutral amino acids in the Ehrlich cell. $J$. gen. Physiol. 50, 203-224.

Jaszczak, S., Hafez, E.S.E., Moghissi, K.S. \& Kurrie, D.A. (1972) Concentration gradients of amino acids between the uterine and blastocoelic fluid in the rabbit. Fert. Steril. 23, 405-409.

Johnson, M.H. (1981) Membrane events associated with the generation of a blastocyst. Int. Rev. Cytol. Suppl. 12, 1-37.

Johnson, M.H. \& Ziomek, C.A. (1981) The foundation of two distinct cell lineages within the mouse morula. Cell 24, 71-80.

Lindqvist, I., Einarsson, B., Nilsson, O. \& Ronquist, G. (1978) The in vivo transport of ${ }^{14}[\mathrm{C}]$-L-aminoisobutyric acid into mouse blastocysts during activation for implantation. Acta physiol. scand. 102, 477-483.

Oxender, D.L. \& Christensen, H.N. (1963) Distinct mediating systems for the transport of neutral amino acids by the Ehrlich cell. J. biol. Chem. 238, 3686-3699.

Pratt, H.P.M., Chakraborty, J. \& Surani, A. (1981) Molecular and morphological differentiation of the mouse blastocyst after manipulations of compaction using cytochalasin D. Cell 26, 279-292.

Schultz, G.A., Kaye, P.L., McKay, D.J. \& Johnson, M.H. (1981) Endogenous amino acid pool sizes in mouse eggs and preimplantation embryos. J. Reprod. Fert. 61, 387-393.

Tasca, R.J. \& Hillman, N. (1970) Effects of actinomycin $\mathrm{D}$ and cycloheximide on RNA and protein synthesis in cleavage stage mouse embryos. Nature, Lond. 225, 1022-1025.

VanVinkle, L.J. \& Dabich, D. (1977) Transport of naturally occurring amino acids and $\gamma$-aminoisobutyric acid by normal and diapausing mouse blastocysts. Biochem. Biophys. Res. Commun. 78, 357-363.

Whittingham, D.G. (1971) Culture of mouse ova. $J$. Reprod. Fert., Suppl. 14, 7-21.

Ziomek, C.A. \& Johnson, M.H. (1980) Cell surface interaction induces polarization of mouse 8-cell blastomeres at compaction. Cell 21, 935-942.

Ziomek, C.A., Schulman, S. \& Edidin, M. (1980) Redistribution of membrane proteins in isolated mouse intestinal epithelial cells. J. Cell Biol. 86, 849-857.

Received 26 August 1981 